\title{
Peter Blundell Jones:
}

\section{Eamonn Canniffe}

Peter Blundell jones served as a valued member of arq's Editorial Board since the journal's inception and he was a frequent contributor to the journal, sometimes writing in collaboration with his graduate students. His life's work was a reaction against the 'construction driven' orthodox modernism that he encountered as a student in the late $1960 \mathrm{os}$. He discovered that 'there was an alternative modernist line, deeper and more subtle' and his meticulously researched books accounted for some of its champions: Eric Gunnar Asplund, Hugo Häring, Peter Hübner, and Hans Scharoun among others. He also plotted an alternative history of modernism published as Modern Architecture Through Case Studies. More recently, he deepened his concern with participatory and 'vernacular' architectures, exploring how people have built without architects. His most recent book Architecture and Ritual, published just before his untimely death, developed these interests.

PBJ (as he was universally known) studied at the Architectural Association (AA) School of Architecture in London between 1966 and 1972 where his tutors included James Gowan and Peter Smithson. Setting out the context of architectural debate and exploration to which his professional life would be devoted, the choice of the German architect Hans Scharoun as the subject of his dissertation at the AA proved crucial. Scharoun's major built work, the Berlin Philharmonie (completed in that divided city in 1963), was a particular representation of the type of architecture that appealed to the young Englishman, contemporary in its technological expression

\section{9-2016}

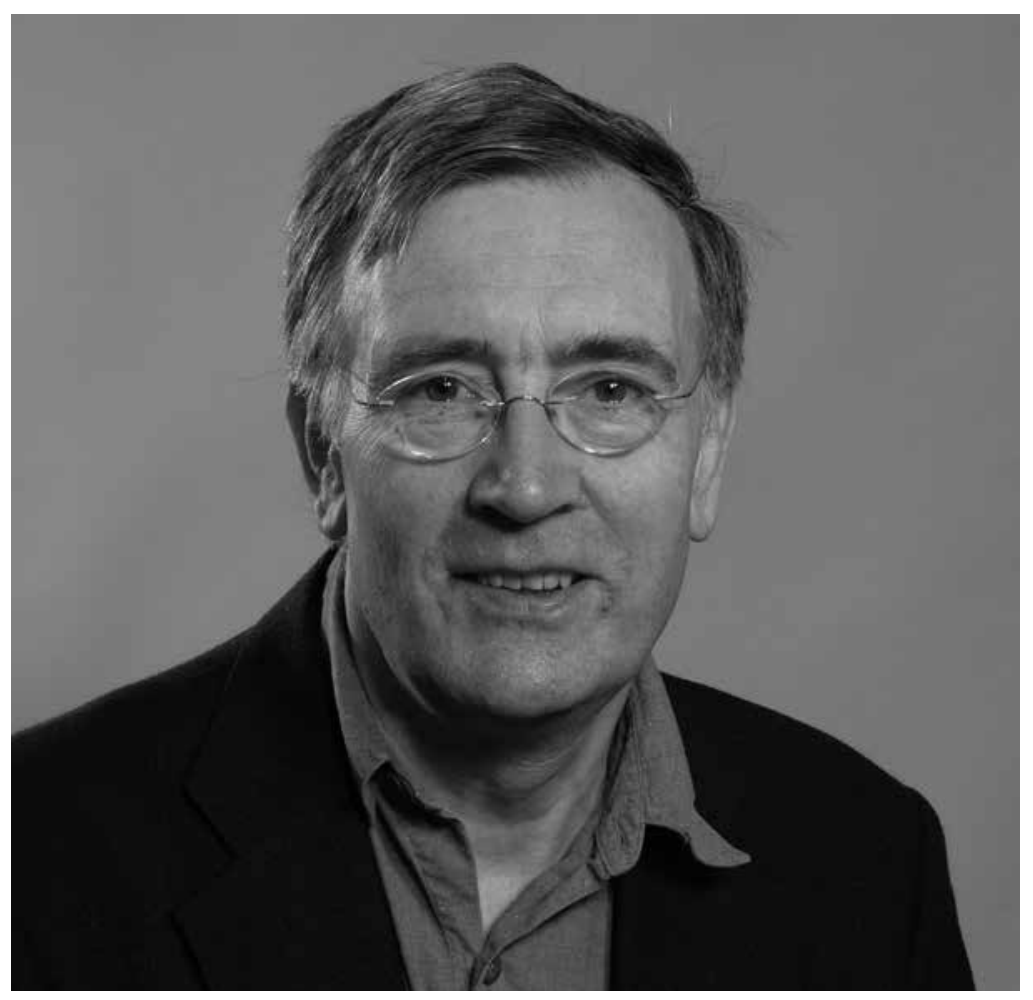

1 Peter Blundell jones

but not determined formally by the orthodox expression of the International Style. In his choice, Blundell Jones was in tune with growing revolt against the restrictive utilitarianism in architecture that characterised much construction in the postwar decades in the West, and the turn towards alternative possibilities that had largely been ignored in the record that was then predominant, crafted by influential writers such as Pevsner and Banham. The questioning of received wisdom and the conventions of architectural design where they had no useful basis would also become a motif of Peter's teaching and criticism over the subsequent decades. But his study of Scharoun gained him his first academic post in 1978 at the Department of Architecture in Cambridge, then headed by Colin St John Wilson. During those years the ubiquitous advertising slogan 'Sch ... you know who!' had a special meaning within the walls of the school's home in Scroope Terrace.

A wider professional audience became familiar with Peter's writing from the mid-1970s onwards in the pages of The Architectural Review. The range broadened in the 1980 s through the AJ Masters of Building series that 


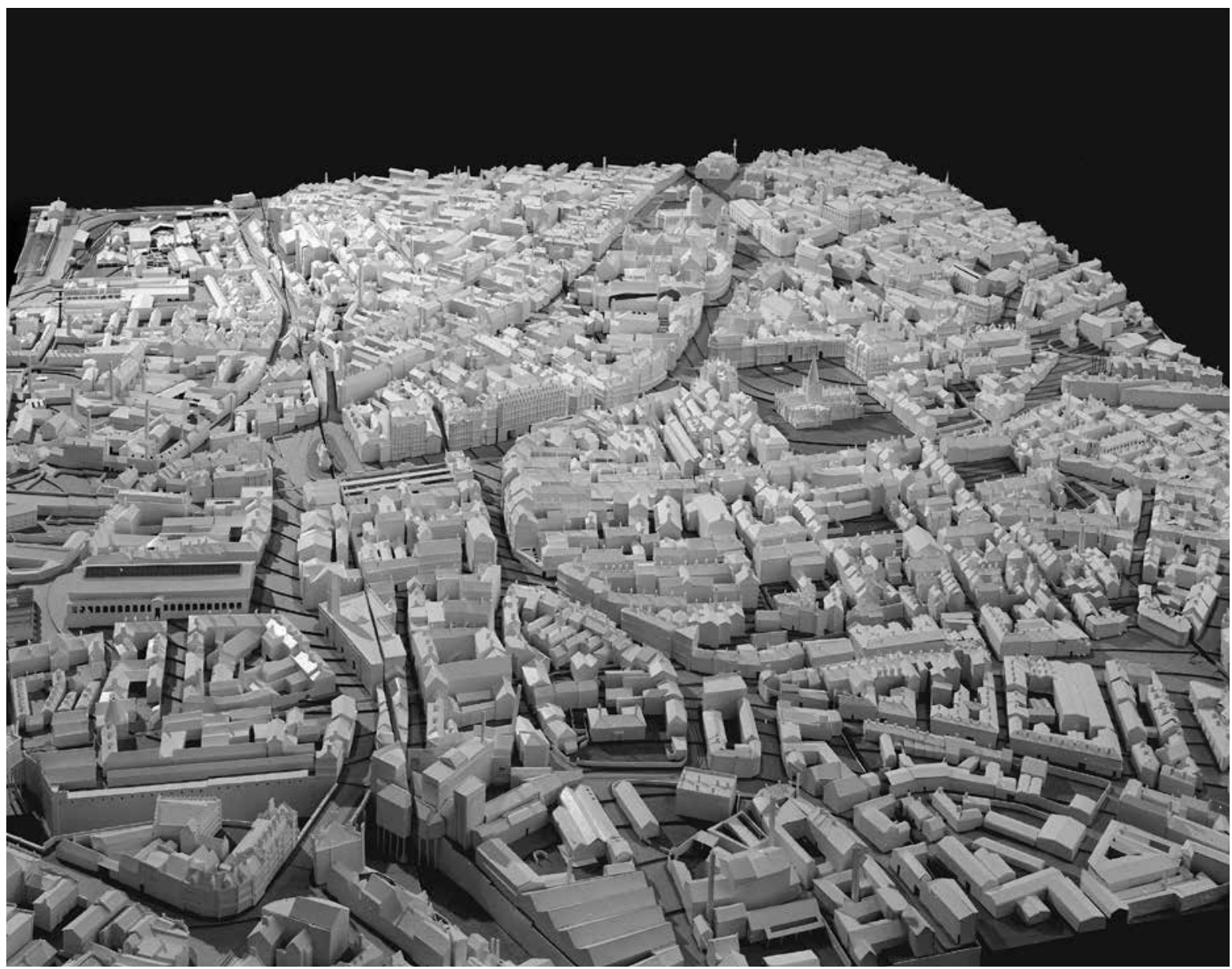

2 Photograph of the Sheffield 1900 model constructed by MArch students at the University of Sheffield

presented a series of historical case studies in the context of contemporary practice, analysed and critiqued as if newly built. The short case study exploring thoroughly the many changes and conflicts that resulted in significant buildings became a format that Peter would pursue in two later volumes surveying significant twentieth-century architecture. It was the premise of Peter's work that there should be no great distinction between the academy and the profession, research, and practice.

Therefore, as an educator, Peter developed an increasingly rare synergy between his pedagogical, design, and research activities. At Sheffield University, where he was appointed Professor of Architecture in 1994, generations of students had their knowledge of architecture illuminated and broadened by his teaching both of 'indigenous' architecture and that of the modern movement, as well as by the organisation of postgraduate seminars, the Forum, which explored particular issues through debate or presentations by eminent visiting speakers. The dissertations that resulted were one outcome (he served as a judge of the RIBA Dissertation Prize over a number of years) but they also took non-literary forms. Blundell Jones also organised exhibitions, at the RIBA of the work of Scharoun in 1995, for example, and Häring in 1999 featuring models made by his Sheffield students. The Sheffield 1900 project involved the painstaking reconstruction of the city at that date by successive teams of M.Arch students through documents, archives and the construction of a large citywide model at 1:500 scale, initially presented as an exhibit during the millennium year. In other fields, Peter's work as an architect - particularly the project for the reconstruction of Padley Mill, his family home in Derbyshire explored the world of industrial archaeology that represented a strand of activity that might be termed radical conservation. In the international sphere, his work with graduate research students took on a global perspective that explored the architecture, landscape, and urbanism of different cultures that has a profound worldwide legacy through the ongoing careers of his many doctoral students.

While many other architectural teachers were rediscovering the classical tradition as a response to the failure of modernism, Peter offered a different history and series of future possibilities based on themes drawn from arts and crafts traditions, contemporary constructional technology, and social engagement. Peter was an early advocate of the work of Lucien Kroll and his participatory design practices, and this would develop into a strong theme in the pedagogy of the Sheffield School of Architecture. Peter's name became most associated with the exposure of this 'alternative tradition of modern architecture', the organic and humanist inspired work of largely northern European architects who complemented or in some instances stood in direct opposition to the functionalist orthodoxy of the machine aesthetic. His exploration of German twentieth-century architecture stretched back to the expressionist projects of the early decades around the First World War and its re-emergence 
after 1945. Coming to the fore in the era of postmodernism, the apparent compositional freedom and strong sense of materiality evident in the work of Scharoun, Häring and (in a younger generation) Behnisch presented an architecture which was social in its focus rather than compositional or historicist. His monographs reintroduced Scharoun into mainstream academic discourse as a figure that had been obscured by historical circumstance and his further books on Häring and then Asplund explored the roots of this particular branch of modern architecture in a way that defied easy or restrictive categorisation. But, particularly in his enduring contributions to The Architectural Review, he also exposed the diverse work of many contemporary architects. This research, writing, and publication was united by the enthusiasm that Peter had for exploring architecture, questioning its regular or routine forms, and joyously celebrating the unique creation that expressed some qualities of craft, place, and time. The influence of countercultural attitudes from the period of his architectural education in the 196os, combined with the diversity of his research
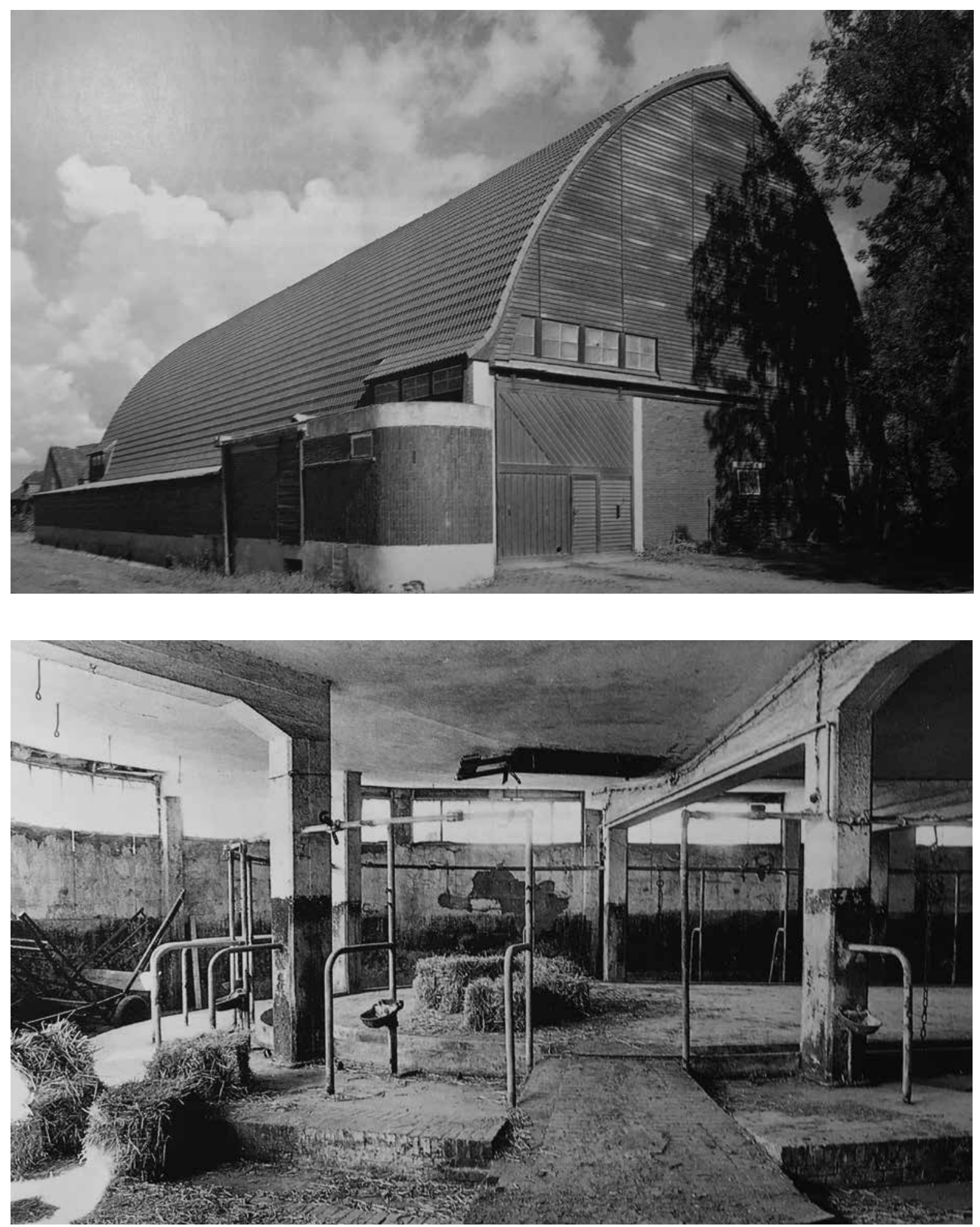

3a-b Hugo Häring's Cowshed at Gut Garkau farm, 1923-26 
students, his teaching, and his personal research resulted in what was to prove his last publication, Architecture and Ritual. The book explores the relationship between a locationally diverse range of building types and the societal structures they reflect, seeing common patterns but different expression.

Despite the recent tendencies of academic life, Peter's work demonstrated the lasting impact of his enthusiasm, design skills and scholarship, a combination that architectural education always needs. At an event held in Peter's memory at the University of Sheffield in November 2016, family, friends, colleagues, and students remembered him in a sequence of heartfelt tributes. Xiang Ren, a current postgraduate student at Sheffield, spoke movingly of the experience of studying with Peter and the tutorial process in both its formal aspects and its informal context that had a deep effect on him. Jan Woudstra from the Department of Landscape at Sheffield spoke about the importance of interdisciplinary dialogue in the development of Peter's work, and how the East-West seminars contributed to Architecture and Ritual, which he thinks will be Peter's most influential publication as it firmly builds a bridge outside the architectural discipline. Cathy Burke, a neighbour as well as a collaborator, spoke about their research on educational environments, a strand of his work that stretched all the way back to his study of Scharoun's schools. Representing his international influence, the architect Peter Hübner spoke about the empathetic response with which his practice's work was received and how the participatory procedures embodied in his schools and kindergartens struck a chord in Peter's educational interest. Former colleagues Bryan Lawson and Jeremy Till spoke about his work at Sheffield, while the writer Fiona MacCarthy, also a Derbyshire neighbour, placed Peter's work and their shared interests in its historical, social, and personal context. To close the evening Peter's wife Chrissie Poulson spoke about the private family man and revealed that he introduced her to the significance of Hugo Häring's cowshed on their second date.
There was perhaps a curious irony that Peter's career promoting the organic and contextual should be associated with the crystalline utopianism of Sheffield's Mies-inspired Arts Tower, the tallest building in the city (see pp. 298-312 in this arq). That on the day of his funeral the blinds were all drawn in the five floors of the tower occupied by the Architecture school was an affectionate community ritual he would have appreciated, and understood as an especially architectural mark of respect.

Peter Blundell Jones, historian and architect (born 4 January 1949; died 19 August 2016) is survived by his second wife, Christine Poulson, their daughter Anna, and by the two children from his first marriage to Rosalind Barron, Timothy and Claire.

\section{EAMONN CANNIFFE}

Eamonn Canniffe is Principal Lecturer at Manchester School of Architecture, UK. He was co-author with Peter Blundell Jones of Modern Architecture through Case Studies 1945-1990 (2007) a Korean language edition of which will be published in 2017.

\section{Illustration credits}

arq gratefully acknowledges: Peter Blundell Jones, 3 Sheffield University School of Architecture, 1, 2 